\title{
PENYESUAIAN PERKAWINAN PADA WANITA YANG MENIKAH MELALUI PROSES TA'ARUF
}

\section{MARITAL ADJUSMENT FOR MARRIED WOMEN THROUGH THE TA'ARUF PROCESS}

\author{
Nurul Aprilini Nusbah ${ }^{1}$, Waode Suarni ${ }^{2}$,Eve Herik ${ }^{3}$ \\ Program Studi Psikologi
}

Fakultas Keguruan dan Ilmu Pendidikan, Universitas Halu Oleo

aprilininusbah21@gmail.com ${ }^{1}$,waode.suarni@gmail.com ${ }^{2}$, herick.eva@gmail.com ${ }^{3}$

\begin{abstract}
ABSTRAK: Penyesuaian perkawinan adalah penyesuaian yang dilakukan suami dan istri meliputi penyesuaian pada pasangan, penyesuaian seksual, penyesuaian keuangan dan penyesuaian dengan keluarga pasangan. Wanita dinilai lebih baik dalam penyesuaian perkawinan karena banyaknya peran yang dijalani dalam rumah tangga. Dalam menuju perkawinan salah satu cara yang dapat digunakan untuk mengenal pasangan adalah dengan proses ta'aruf. Ta'aruf memiliki masa perkenalan yang singkat sehingga akan mempengaruhi penyesuaian dalam perkawinan. Penelitian ini bertujuan untuk mengetahui penyesuaian perkawinan pada wanita yang menikah melalui proses ta'aruf. Metode yang digunakan adalah metode kualitatif dengan desain penelitian studi kasus. Subjek dalam penelitian ini berjumlah 5 orang wanita yang menikah melalui proses ta'aruf dengan rentang usia perkawinan 1-5 tahun diambil dengan teknik purposive sampling dan 9 orang informan pendukung. Metode pengumpulan data diperoleh melalui wawancara dan observasi. Berdasarkan hasil penelitian menunjukkan bahwa ta'aruf yang sesuai dengan adab-adab dalam islam akan memberi dampak pada penyesuaian perkawinan yang baik. Kelima subjek dalam penelitian ini mampu melakukan penyesuaian perkawinan dalam aspek penyesuaian pada pasangan, penyesuaian seksual, dan penyesuaian keuangan. Namun, kelima subjek kurang dalam aspek penyesuaian terhadap keluarga pasangan.
\end{abstract}

Kata kunci: Ta'aruf, Wanita yang menikah melalui proses ta'aruf, penyesuaian perkawinan

ABSTRACT: Marriage adjustments are adjustments that made by husband and wife, including adjustments in partners, sexual adjustments, financial adjustments and adjustments to the spouse's family. Women are considered better at marriage adjustment because of the many roles they play in the household. In approaching marriage one of the methods that can be used to get to know your partner is the ta'aruf process. Ta'aruf has a short introduction period so that it will affect marriage adjustments. This study aims to determine marital adjusment for married women through the ta'aruf process. The method used is a qualitative method with a case study research design. The subjects in this study amounted to 5 women who married through the ta'aruf process with a marriage age range of 1-5 years taken by purposive sampling technique and 9 supporting informants. Data collection methods obtained through interviews and observations. Based on the results of the study showed that ta'aruf in accordance with manner in islam will have an impact on good marriage adjustments. The five subjects in this study were able to make marriage adjustments in aspects of partner adjustment, sexual adjustment, and financial adjustment. However, the five subjects were less in the aspect of adjusting to their spouse's family

Keywords: Ta' aruf, woman who married by ta'aruf process, marriage adjustment. 


\section{Pendahuluan}

Hurlock (1980) berpendapat bahwa menikah termasuk dalam salah satu tugas perkembangan individu. Menikah menurut Gardner dan Kosmitzky (Papalia, Old \& Feldman, 2008) diartikan sebagai wadah yang memungkinkan untuk pembagian tugas di dalam satuan penggunaan sumber daya dan kerja.

Dalam perjalanannya menuju perkawinan, individu menempuh proses perkenalan yang paling umum terjadi yakni melalui proses pacaran. Namun, terdapat pula individu yang memilih untuk tidak berpacaran yakni dengan proses ta'aruf.

Menurut Shaifiyah (2017) ta'aruf berasal dari kata Bahasa Arab, yaitu arafaya'rifu yang artinya kenal (tahu). Sedangkan ta'aruf sendiri mengandung makna 'perkenalan'. Ta'aruf adalah proses saling kenal-mengenal sebelum menikah dengan dilandasi ketentuan agama (Shaifiyah, 2017). Tujuannya agar sampai ke jenjang pernikahan (Faiza, 2018).

Pada proses ta'aruf, masa perkenalan relatif singkat sehingga membuat pasangan suami istri mengalami tantangan saat perkawinan. Sebagai contoh, pasutri mengalami masa penyesuaian diri yang relatif lebih lama dibandingkan pasutri yang menikah melalui proses berpacaran (Rosita \& Indriani, 2014). Tantangan ini terkait dengan belum mendalamnya pengetahuan individu mengenai pasangan, yang mana kondisi ini menuntut mereka untuk lebih dapat beradaptasi.

Penyesuaian diri dianggap hal yang penting karena jika terjadi ketidakmampuan atau kesulitan dalam penyesuaian diri akan menyebabkan terjadi masalah atau konflik-konflik dalam rumah tangga yang dapat berujung pada perceraian. Hal ini diperkuat dengan data dari penyebab perceraian di Kota Kendari, pada tahun 2017 tercatat 3 faktor tertinggi. Pertama, perselisihan dan pertengkaran terus menerus sebanyak 1.173 perkara. Kedua, meninggalkan salah satu pihak sebanyak 444 perkara. Ketiga, ekonomi sebanyak 279 perkara (Direktorat Jendral Badan Peradilan Agama [Badilag] Mahkamah Agung, 2014). Dari data faktor penyebab perceraian tahun 2017 di Pengadilan Agama di Kota Kendari terlihat lebih didominasi alasan/faktor perselisihan dan pertengkaran terus menerus yang menempati urutan pertama terbanyak.

Perselisihan antara suami istri merupakan permasalahan yang terkait dengan penyesuaian perkawinan sehingga untuk dapat menjalani kehidupan perkawinan dengan baik, baik suami maupun istri harus dapat menyesuaikan diri dalam perkawinan. Lestari (2013) menyebutkan bahwa meningkatnya angka perceraian adalah salah satu indikasi merosotnya nilai keluarga dan kegagalan penyesuaian perkawinan.

Menurut Hurlock (1980) penyesuaian perkawinan meliputi empat hal, yaitu penyesuaian dengan pasangan, penyesuaian seksual, penyesuaian keuangan dan penyesuaian dengan keluarga pihak masing-masing pasangan.

Pada prosesnya, penyesuaiaan perkawinan lebih baik pada istri karena dinilai dari banyaknya peran yang dijalani dalam rumah tangga misal menjadi ibu, istri, dan wanita karir bagi yang bekerja. Hal ini didukung oleh hasil penelitian Jasri dan Joseph (2013) bahwa perempuan memiliki penyesuaian perkawinan yang lebih baik dan kedewasaan emosional meskipun tekanan yang mereka hadapi dalam menyeimbangkan perannya dirumah maupun ditempat kerja.

Kompleksitas penyesuaian di tahun pertama dan kedua perkawinan menurut Hurlock (1980) ini terkadang menjadi pemicu kegagalan ketercapaian tujuan perkawinan untuk membina keluarga yang harmonis, sehingga penyesuaian diri dalam perkawinan merupakan masalah yang tidak boleh disepelekan. Oleh karena itu, dalam proses ta'aruf terutama individu yang menjalaninya harus siap dengan konsekuensi apapun yang ada pada calon 
pasangan hidupnya, karena pada umumnya individu tidak mengetahui benar kepribadian orang yang akan menemani kehidupannya.

Dalam wawancara yang dilakukan oleh peneliti pada salah satu informan perempuan yang menikah melalui proses ta' aruf berinisial U, mengatakan:

“...khawatir nanti... misalnya tidak cocok karakter begitu ya. tipikal misalnya saya karakternya begini-begini jangan sampai tidak cocok dengan dia, saya juga kan belum terlalu kenal orangnya seperti apa...."

Selain itu, peneliti juga mewawancarai informan lain inisial $\mathrm{G}$, menyatakan:

"...suamiku itu sebelumnya orang yang sama sekali saya nda kenal, jadi pas menikah saya harus menyesuaikan betulbetul dengan sifatnya..butuh waktu lama juga saya bisa mengerti hal-hal yang disukai dan tidak. Beruntungnya suamiku juga orangnya terbuka jadi kalau ada sesuatu langsungji dia sampaikan ke saya."

Penuturan $\mathrm{U}$ dan $\mathrm{G}$ dapat disimpulkan bahwa tantangan yang dihadapi individu yang melakukan ta'aruf adalah belum mendalamnya pengetahuan mereka tentang karakter pasangan. Dengan demikian, pasangan yang menikah melalui ta'aruf perlu lebih ekstra membuka diri untuk mempermudah proses penyesuaian diri setelah menikah. Hal ini didukung oleh penelitian Kusuma (2014), yang mengungkapkan bahwa waktu perkenalan yang singkat membuat individu yang melakukan ta'aruf sebelum menikah kurang mengenali pasangannya dengan baik sehingga di awal-awal perkawinan mengalami kesulitan dalam penyesuaian diri dengan pasangan yang berdampak pula pada kepuasan perkawinan.

Dalam penelitian Citra (2013) menunjukkan bahwa ternyata tidak sedikit pasangan yang menikah melalui proses ta'aruf akhirnya bercerai, bahkan ada yang usia perkawinannya satu minggu. Salah satu kasus nyata adalah perceraian pada perkawinan yang diawali dengan proses ta'aruf yang dialami oleh Hafiz Muda Taqy Malik dengan anak perempuan pengacara ternama Salmafina Sunan. Dilansir dalam sebuah artikel pemberitaan Liputan6.com bahwa salah satu penyebab perceraian keduanya adalah perbedaan prinsip dan kurangnya penyesuaian diri keduanya (Saputra, 2017).

Di beberapa penelitian, perkawinan yang dilalui dengan proses ta'aruf juga lebih bahagia dan tingkat kepuasannya jauh lebih tinggi dibanding dengan perkawinan tanpa proses ta'aruf, hal ini di paparkan dalam penelitian Ardhianita dan Andayani (2005) mengungkapkan bahwa kepuasan perkawinan pasangan yang menikah tanpa pacaran berada pada nilai yang lebih tinggi dibandingkan pasangan yang menikah dengan pacaran. Selain itu, Saafa (Wuryandi, Indrawati \& Siswati, 2010) mengungkapkan bahwa pacaran justru memberi dampak negatif terhadap kepuasan perkawinan yang pada akhirnya membuat perkawinan tidak stabil karena orang yang berpacaran cenderung menampilkan diri di depan pacarnya tidak secara apa adanya.

Dari uraian di atas, dapat disimpulkan bahwa penyesuaian diri dalam perkawinan berperan penting pada perkawinan baik yang di awali dengan proses pacaran maupun ta'aruf. Pada istri, penyesuaian perkawinan lebih baik dibanding dengan suami menjadikan peneliti tertarik untuk meneliti penyesuaian perkawinan pada wanita yang menikah melalui proses ta'aruf. Mengingat masa ta'aruf yang dinilai singkat menyebabkan perkenalan yang dilakukan tidak begitu mendalam sehingga akan mengarah pada penyesuian yang dilakukan.

Penelitian ini bertujuan untuk mengetahui bagaimana penyesuaian perkawinan pada wanita yang menikah melalui proses ta'aruf. Adapun manfaat. Dengan adanya penelitian ini, penulis berharap dapat memberikan edukasi dan memberikan gambaran penyesuaian 
perkawinan pada wnaita yang menikah melalui proses ta'aruf.

\section{Metode Penelitian}

Penelitian ini adalah penelitian kualitatif dengan desain studi kasus. Yang dilakukan pada tanggal 3 September yang dilakukan pada tanggal 29 September 2019 sampai 24 November 2019 di Kota Kendari dan Kabupaten Konawe oleh 5 orang subjek penelitian yang dipilih berddasarkan teknik pengambilan sampel purposive sampling.

Teknik pengumpulan data menggunakan teknik wawancara, observasi dan dokumentasi. Teknik analisis data dengan melakukan analisis sebelum di lapangan, reduksi data, penyajian data verifikasi. Teknik keabsahan data menggunakan uji kredibilitas yakni triangulasi yang terdiri dari:

1. Triangulasi sumber

Dengan melakukan wawancara pada 9 informan pendukung.

2. Triangulasi waktu

Mewawancarai subjek utama dalam waktu yang berbeda.

\section{Hasil Penelitian Dan Pembahasan Hasil Penelitian}

\section{Penyesuaian dengan pasangan}

Kriteria utama subjek dalam penelitian ini adalah melihat dari segi agama yang baik dan sekufu dalam wawasan keagamaan. Subjek CC dan RT memiliki kriteria tambahan yakni suami penghafal Al-Qur'an. Oleh karena itulah, mereka tidak merasakan kekecewaan yang berlebihan terhadap kekurangan fisik dan karakter yang adapada pasangan mereka.

Terkait penyesuaian dengan pasangan, terungkap melalui wawancara pada subjek AA ketika menikah harus membiasakan diri mendapatkan persetujuan suami sebelum melakukan aktifitas di luar rumah. Sedangkan subjek TA yang mengesampingkan urusan perkuliahan demi tanggung jawab dalam mengurus anak. Subjek CC yang berhenti bekerja karena permintaan dari suami dan fokus untuk mengurus pasangan dan anak di rumah. Subjek RT yang menjalani peran sebagai ibu, istri dan pekerja secara bersamaan, serta subjek AS yang baru memiliki anak. Kelima subjek menghadapi perubahan dalam pola hidup mereka, namun mereka menyadari adanya peran dan tanggung jawab masing-masing, sehingga tehindar dari adanya konflik-konflik emosional akibat perubahan pola hidup.

\section{Penyesuaian Seksual}

Menghadapi penyesuaian seksual kelima subjek melakukan edukasi seksual sebelum menikah dengan membaca buku-buku, dan bertanya kepada orang-orang yang telah memiliki pengalaman terkait hubungan seksual suami dan istri. Selain itu, mereka juga melakukan diskusi dan kesepakatan dengan pasangan sebelum melakukan hubungan seksual terkait dengan perilaku seksual yang dilandaskan pada adab-adab islami.

\section{Penyesuaian Keuangan}

Dalam melakukan penyesuaian keuangan dalam perkawinan, kelima subjek memiliki persamaan pada beberapa hal dalam hubungan mereka. Persamaan mencakup hal terkait keuangan dan pembagian peran. Kelima subjek mendapatkan uang belanja dari suami mereka dan berperan sebagai pengatur keuangan dalam rumah tangga.

Peran tersebut didasari oleh peran istri sebagai ummuwarabbtul bait sebagai ibu dan pengatur rumah tangga. Selain itu, kelima subjek tidak mempermasalahkan penghasilan yang diperoleh dari suami mereka. Mampu 
menerima berapapun uang yang diberikan suami untuk keperluan rumah tangga.

Untuk beberapa subjek seperti AA dan AS merasa tidak harus mengetahui jumlah gaji atau penghasilan yang diperoleh oleh suami mereka karena merasa lebih tenang. Dengan kata lain, kelima subjek meyakini bahwa kondisi keuangan yang dialami adalah atas kehendak Allah SWT. sehingga dalam menghadapi masalah keuangan mereka mampu menerima dengan rasa syukur dan akan berujung pada terwujudnya penyesuaian keuangan mereka.

\section{Penyesuaian terhadap Keluarga Pasangan}

Subjek AA, TA, CC, dan RT sepakat untuk berpisah dengan keluarga dan tidak tinggal dalam satu rumah dengan orang tua. Alasan untuk berpisah dengan keluarga adalah merasa lebih nyaman, serta menghindari konflik yang terjadi antara mertua dan menantu. Selain itu, mengurangi keterlibatan keluarga dalam urusan rumah tangga mereka.

Pada subjek AA dalam hubungan dengan keluarga pasangan merasa mampu membaur dan bersosialisai ketika bertemu secara langsung. Namun, subjek AA merasa kurang nyaman dengan ayah mertua yang memiliki kebiasaan dalam berhutang. Kebiasaan berhutang ayah mertua tersebut membuat AA dan suami harus selalu membantu dalam melunasinya.

Memilih untuk tidak tinggal bersama keluarga khususnya keluarga pasangan membuat beberapa subjek kurang dapat bersosialisasi dengan baik kepada keluarga pasangan. Subjek TA yang tinggal berjauhan dengan keluarga suami membuat TA merasa kurang menjalin kedekatan. Hal tersebut ditunjukkan dengan perasaan sungkan dan canggung saat bertemu dengan mertua.

Pada subjek CC yang sebelumnya tinggal bersama keluarga suami mengaku bahwa memilih untuk berpisah karena merasa kurang nyaman dengan ibu mertua yang selalu mengurus makanan suami CC. Ibu dari suaminya menilai bahwa $\mathrm{CC}$ belum mengetahui masakan yang biasa di konsumsi oleh keluarga mereka. Hal yang sama dirasakan pula oleh RT yang merasa kurang dekat dengan keluarga suami.

Subjek AS yang tetap tinggal bersama orang tua karena AS dan suami belum memiliki tempat tinggal pribadi dan kondisi orang tua suami yang lemah dan sakit-sakitan. Menghadapi situasi tersebut, AS merasa memiliki kebutuhan lebih banyak dan waktu yang sedikit untuk membantu mengurus keluarga suami.

Bantuan keuangan yang diberikan pasangan kepada keluarga asalnya tidak mempengaruhi hubungan subjek dengan pasangan. Namun, hal tersebut memberikan dampak pada hubungan subjek dengan keluarga pasangan. Seperti halnya keluarga pasangan subjek AA yang meminta bantuan keuangan untuk melunasi hutang. Kebiasaan berhutang mertua laki-laki subjek AA tersebut membuat hubungan mereka menjadi renggang dan merasa canggung saat bertemu.

\section{Pembahasan}

Wanita yang menikah melalui proses ta'aruf dalam penelitian ini berpendapat bahwa ta'aruf merupakan salah satu jalan yang dianjurkan oleh islam, karena dalam islam tidak kenal budaya pacaran pra menikah. Hal itu sejalan dengan pendapat Faiza (2018) mengatakan bahwa ta'aruf adalah jalan mencari jodoh yang cocok dan seiman, dengan cara yang diridhoi Allah SWT. 
Dalam penelitian Citra (2013) ditemukan bahwa pasangan dari perkawinan ta'aruf yang bercerai menjalani proses ta'aruf yang masih memiliki unsur khalwat atau berdua-duaan baik secara langsung ataupun melalui media komunikasi seperti handphone. Sedangkan pada proses ta'aruf yang dijalani oleh kelima subjek dalam penelitian ini sangat menjaga diri dari unsur khalwat.

Proses ta'aruf itu sendiri memiliki adab-adab yang harus dijalani salah satunya adalah tidak berduaan atau khalwat karena beberapa pendapat mengatakan bahwa chattingan antara lawan jenis tanpa ada hal yang syar'i hukumnya sama seperti berkhalwat (Litatalia, 2018). Menurut Abdurrahman (2013) Individu yang tidak mengikuti prinsip dan adab-adab dalam proses ta'aruf maka dianggap mencacatkan ta'aruf itu sendiri dan perkawinan yang dijalani dapat berkurang berkahnya.

Dari hasil analisis wawancara, penyesuaian perkawinan yang dilakukan oleh perempuan yang menikah melalui proses ta'aruf mencakup empat hal, yakni penyesuaian dengan pasangan, penyesuaian seksual, penyesuaian keuangan, dan penyesuaian dengan keluarga pasangan.

\section{Penyesuaian dengan pasangan}

Menurut Hurlock (1980) dalam memilih pasangan, baik pria maupun wanita akan dipengaruhi oleh konsep pasangan ideal mereka. Semakin individu tidak terlatih dalam menyesuaikan diri terhadap realitas pasangan yang diidamkan maka akan semakin sulit penyesuaian dilakukan terhadap pasangan.

Kelima subjek tidak merasa kecewa dan mampu menerima kondisi pasangan mereka karena setiap pasangan tidak menitikberatkan pemilihan calon pasangan pada aspek fisik dan karakter semata. Kriteria utama mereka adalah melihat dari segi agama yang baik dan sekufu dalam wawasan keagamaan. Oleh karena itulah, mereka tidak merasakan kekecewaan yang berlebihan terhadap kekurangan fisik dan karakter yang ada pada pasangan mereka.

Dasar berumah tangga untuk beribadah kepada Allah SWT menjadikan individu bisa menerima perbedaan dan kelemahan pada diri suami (Abdurrahman, 2013). Hal tersebut sejalan dengan penjelasan pada subjek penelitian ini, beberapa hal pokok yang menjadi dasar mereka dalam hal menerima dan menyesuaikan diri dengan kekurangan fisik dan karakter pada pasangan yaitu; ridha dan bersyukur pada kepada Allah SWT, intropeksi diri terhadap kekurangan diri sendiri, melihat kelebihan-kelebihan pasangan, dan senantiasa berpikir positif terhadap anugerah Allah SWT.

Penyesuaian dengan pasangan yang baik, harus saling membantu dalam memenuhi kebutuhan yang berasal dari pengalaman awal mereka (Hurlock, 1980). Berdasarkan hasil wawancara, kelima subjek membantu pasangan mereka dalam memenuhan kebutuhannya seperti turut bekerja, melakukan usaha kecil-kecilan dirumah, dan mengatur keuangan.

Dalam penyesuaian dengan pasangan, Hurlock (1980) juga mengemukakan bahwa semakin sama latar belakang suami dan istri, maka semakin mudah untuk saling menyesuaikan diri. Hal tersebut menjadi salah satu pertimbangan kelima subjek dalam memilih pasangan mereka melalui proses ta'aruf. Latar belakang agama yang baik, dan sekufu dalam hal wawasan keagamaan menjadi kriteria yang harus dimiliki calon pasangan ta'aruf. Selain latar belakang yang sama, setiap pasangan mempunyai konsep yang pasti mengenai bagaimana 
seharusnya peranan seorang suami dan istri, atau setiap individu mengharapkan pasangannya dapat menjalankan perannya (Hurlock, 1980). Kelima subjek sepakat bahwa dalam perkawinan mereka harus menjalankan peran masing-masing. Peran sebagai ummuwarabbtul bait sebagai ibu dan pengatur rumah tangga.

Masing-masing aggota dalam keluarga mempunyai hak dan kewajibannya sendiri-sendiri, mempunyai status dan peranan sendiri-sendiri. Oleh karena itu, diperlukan sikap saling pengertian satu dengan yang lainnya (Walgito, 2017).

Terkait dengan penyesuaian pasangan, kelima subjek mampu menghadapi tahapan dan tantangan karena memiliki tujuan perkawinan berlandaskan agama, menyadari peranan masing-masing dan memiliki sikap saling pengertian.

\section{Penyesuaian Seksual}

Menghadapi penyesuaian seksual kelima subjek melakukan edukasi seksual sebelum menikah dengan membaca buku-buku, searching di internet, dan bertanya kepada orangorang yang telah memiliki pengalaman terkait hubungan seksual suami dan istri. Selain itu, mereka juga melakukan diskusi dan kesepakatan dengan pasangan sebelum melakukan hubungan seksual terkait dengan perilaku seksual yang dilandaskan pada adab-adab islami.

Hal tersebut sejalan dengan pendapat an-Nu'aimi (2019) mengatakan agar suami-istri berhasil dalam berhubungan seksual maka harus mengenali keinginan dan tuntutan masing-masing. untuk mengetahui keinginan dan tuntutan dalam hubungan seksual suami dan istri tentunya diperlukan komunikasi.
Kelima subjek dalam hasil wawancara sepakat bahwa setiap pasangan harus ada keterbukaan satu sama lainnya.

Menghadapi tantangan dalam penyesuaian seksual, kelima subjek melakukan beberapa cara yaitu membekali diri dengan melakukan edukasi seksual, melakukan kesepakatan sebelum melakukan hubungan mengkomunikasikan keinginan seksual dan saling terbuka satu sama lain.

\section{Penyesuaian Keuangan}

Dalam melakukan penyesuaian keuangan dalam perkawinan, kelima subjek memiliki persamaan pada beberapa hal dalam hubungan mereka. persamaan mencakup hal terkait keuangan dan pembagian peran. Kelima subjek mendapatkan uang belanja dari suami mereka dan berperan sebagai pengatur keuangan dalam rumah tangga. Peran tersebut didasari oleh peran istri sebagai ummuwarabbtul bait sebagai ibu dan pengatur rumah tangga. Hal ini diperkuat dengan pernyataan Hardjodisastro dan Hardjodisastro (2010) bahwa suami istri bekerjasama dalam membuat keputusan dalam keluarga akan tetapi para suami cenderung tidak memikirkan pengeluaran keseharian seperti uang belanja karena itu adalah pekerjaan istri.

Selain itu, Kelima subjek tidak mempermasalahkan penghasilan yang diperoleh dari suami mereka. Mampu menerima berapapun uang yang diberikan suami untuk keperluan rumah tangga. Untuk beberapa subjek seperti AA dan AS merasa tidak harus mengetahui jumlah gaji atau penghasilan yang diperoleh oleh suami mereka karena merasa kebih tenang. Uang yang diberikan suami adalah rejeki yang telah ditetapkan 
Allah SWT. Sedikit banyak rejeki tersebut yang terpenting adalah berkahnya, istri haruslah bersikap qana'ah artinya seorang istri rela menerima atau merasa cukup dengan apa yang didapat oleh suami serta menjauhkan diri dari sifat tidak puas dan merasa kekurangan berlebihlebihan (Abdurrahman, 2013).

Dengan kata lain, kelima subjek meyakini bahwa kondisi keuangan yang dialami adalah atas kehendak Allah SWT. sehingga dalam menghadapi masalah keuangan mereka mampu menerima dengan rasa syukur dan akan berujung pada terwujudnya penyesuaian keuangan mereka.

\section{Penyesuaian terhadap Keluarga} Pasangan

Dalam penyesuaian terhadap keluarga pasangan juga akan dihadapkan dengan persoalan pasangan yang membantu keuangan keluarga pasangan atau pasangan yang masih membiayai keluarga asalnya (Hurlock, 1980). Menghadapi hal tersebut, kelima subjek tidak merasa keberatan jika pasangan mereka masih membiayai atau memberikan bantuan keuangan terhadap keluarga asal pasangan.

Bantuan yang diberikan kepada keluarga pasangan merupakan bentuk tanggungjawab dan bakti laki-laki terhadap orang tua mereka. Dalam agama islam, laki-laki tidak akan terputus baktinya kepada orang tua sampai akhir hayatnya. Hal inilah yang menjadi landasan subjek dapat menerima bantuan yang diberikan kepada keluarga pasangan.

Dari uraian diatas, penyesuaian terhadap keluarga pasangan yang dilakukan subjek adalah memilih untuk tidak tinggal bersama keluarga, dan kesadaran akan tanggung jawab pasangan terhadap keluarga pasangan.

\section{Kesimpulan dan Saran Kesimpulan}

Penyesuaian perkawinan yang dijalani kelima subjek memiliki persamaan yakni pada proses yang dijalani mereka menjadikan agama sebagai landasan atau pedoman mereka dalam berumah tangga. Penerimaan pasangan, perilaku seksual, keuangan dan hubungan keluarga juga di atur dalam agama yang menjadikan kelima subjek mampu menghadapi kesulitan penyesuaiannya.

Perbedaan dalam penyesuaian perkawinan pada kelima subjek terletak pada kesulitan atau hambatan yang dialami kelima subjek juga berbeda-beda. Namun, kelima subjek menjadikan landasan keagamaan sebagai solusi untuk dapat menghadapi kesulitan dalam penyesuaian perkawinan. Selain faktor agama, menjalin komunikasi dan keterbukan juga menjadi sangat penting dalam melakukan penyesuaian perkawinan

Penyesuaian perkawinan yang dilakukan oleh kelima subjek dalam penelitian ini, menunjukkan bahwa mereka mampu dalam melakukan penyesuaian pasangan, seksual dan keuangan. Sedangkan pada penyesuaian keluarga mereka mengalami kesulitan untuk menyesuaikan dengan orang tua pasangan. Hambatan yang dialami adalah merasa tidak nyaman dengan perilaku mertua yang sering berhutang, jarang bertemu untuk menjalin komunikasi, memiliki latar budaya yang berbeda, dan kondisi mertua yang sakit-sakitan.

\section{Saran}

1. Pasangan muslim yang ingin menikah

a. Setiap pasangan yang memilih ta'aruf sebagai langkah awal perkawinan sebaiknya memperoleh edukasi pranikah dan mengetahui langkah-langkah yang benar dalam proses ta'aruf.

b. Setiap pasangan yang akan menikah melalui proses ta'aruf 
juga melakukan pengenalan terhadap keluarga calon pasangan.

2. Pasangan yang menikah melalui proses ta'aruf

a. Perkawinan dalam proses ta'aruf untuk dapat menjalin hubungan yang lebih dekat dengan pasangan adalah dengan membangun komunikasi dua arah yang baik, saling terbuka dan saling memberikan pengertian pada pasangan dalam setiap keadaan dan dapat konsisten menjaga hubungan tetap baik pada setiap kondisi.

b. Bagi pasangan ta'aruf yang memilih untuk berpisah dengan orang tua tetap menjalin komunikasi dan menyempatkan waktu untuk bertemu menjalin interaksi satu sama lain terkhusus menantu dan mertua.

c. Bagi pasangan ta'aruf yang tinggal bersama orang tua untuk

3. Peneliti Selanjutnya

Diharapkan dapat melengkapi penelitian tentang penyesuaian perkawinan dengan memperbanyak jumlah subjek penelitian yang bervariasi dari segi perbedaan budaya dan rentang usia suami dan istri.

\section{Daftar Pustaka}

Abdurrahman, Y. (2013). Risalah Khitbah, Panduan Islami dalam Memilih Pasangan \& Meminang. Bogor: Al Azhar Press.

Ardhianita \& Andayani. (2005). Kepuasan Pernikahan ditinjau dari Berpacaran dan Tidak Berpacaran. Jurnal Psikologi, 2 (2), 101-111.

Citra, A. (2013). Penerimaan terhadap Pasangan dan Religiusitas sebagai Kepuasan Pernikahan pada Pasangan yang Menikah melalui Proses Ta'aruf. (Skripsi). Universitas Indonesia, Depok.
Direktorat Jendral Badan Peradilan Agama Mahkamah Agung. (2014, April). Putusan: Publikasi Putusan. badilag.mahkamahagung.go.id.

Diunduh dari: http://badilag. mahkamahagung.go.id/putusan/uncat egorised/ publikasi-putusan

Faiza, A. (2018). Ta'aruf Mati Langkah. Noktah: Yogyakarta.

Hardjodisastro, D \& Hardjodisastro, W. (2010). Ilmu Slamet: Merangkai Mutiara Filsafat Jawa di Era Modernisasi dan Globalisasi.Jakarta: Bhuana Ilmu Populer.

Hurlock, E. B (1980). Psikologi Perkembangan, Suatu Pendekatan Sepanjang Rentang Kehidupan (ed.5). Jakarta: Erlangga.

Jasri, M \& Josep, M. I. (2013). Marital Adjusment and Emotional Maturity among Dual-Career Couples. Journal of Behavioral and Social Sciences, 1(2), 83.

Kusuma, F. (2014). Kepuasan Pernikahan pada Wanita yang Menikah Melalui Proses Ta'aruf. (Skripsi). Universitas Kristen Satya Wacana, Salatiga.

Lestari, S. (2013). Psikologi Keluarga. Jakarta: Kencana Prenada Media Grup.

Litalia. (2018. May). Begini Nikmatnya Menikah denganTa'aruf yang Pacaran Pasti Iri. maumenikah.com. Diunduh dari: https://maumenikah.com/begininikmatnya-nikah-dengan-taarufyang-pacaran-pasti-iri/

Papalia, D. E., Olds. S. W., \& Feldman, R. (2008). Human Development (Psikologi Perkembangan (ed.9). 
Boston: MacGraw Hill Co.

Rosita, K., \& Indriana, Y. (2014).

Pengalaman Subjektif Istri yang Menikah dengan Proses Ta'aruf. Jurnal Psikologi UNDIP, 3 (4).

Saputra, R.A. (2017, April). Rupanya, ini Penyebab Taqy Malik Ceraikan Salmafina Khairunnisa. Liputan6.com. Diunduh dari: https://www.liputan6.com/showbiz/r ead/3208008/rupanya-ini-penyebabtaqy-malik-ceraikan-salmafinakhairunnisa.

Shaifiyah, E. (2017). La Tahzan for True Love Muslimah Percayalah Cinta Sejati Pasti dating Kepadamu. Yogyakarta: Araska.

Walgito, B. (2017). Bimbingan dan Konseling Perkawinan (ed.revisi).Yogyakarta: Andi Offset.

Wuryundari, M., Indrawati, E.S., \& Siswati. (2010). Perbedaan Persepsi Suami dan Istri terhadap kualitas Pernikahan antara yang Menikah dengan Pacaran dan Ta'aruf. Universitas Diponegoro, 16 (3). 